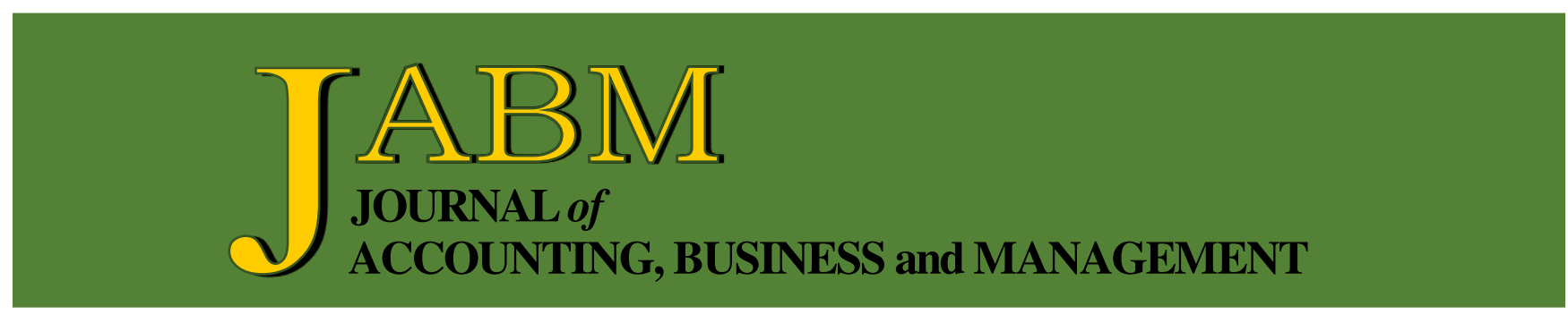

Life Insurance Companies: Determinants of Cost Efficiency and Profitability

Joseph Kwadwo Tuffour, Kenneth Ofori-Boateng, Williams Ohemeng, and Jane Kabukuor Akuaku

Subprime Crisis - A Corporate Acquisition Opportunity?

Vishal Srivastava, Sunder Ram Korivi, and Dipasha Sharma

Consequences of Weak Internal Controls Over Financial Reporting: Foreign versus U.S. Firms

Kathleen Bakarich and Devon Baranek

Impact of Organizational Commitment on Accounting Professionals' Performance: Case of Accounting Firms

Lassaad Abdelmoula and Sami Boudabbous

The Objectives of Sharia Management Accounting Information Reporting: Identification of Values and Characteristics

Sonhaji, Abdul Kadir Usri, and Hedher Tuakia

The Impact of Customer's Perception of the Practices of Corporate Social Responsibility on Purchase Intention

Doaa Abd El Samea and Ahmed Rashed

Corporate Financial Distress: The Impact of Profitability, Liquidity, Asset Productivity, Activity and Solvency

Karikari Amoa-Gyarteng

Determinant Factors of Social Cohesion and Inclusion of Street Vendors in Jakarta: Key Factor Surviving During Covid-19 Pandemic

Beti Nurbaiti 
Journal of Accounting, Business and Management (JABM) vol. 28 no. 2 (2021) 104-115

\title{
Corporate Financial Distress: The Impact of Profitability, Liquidity, Asset Productivity, Activity and Solvency
}

\author{
Karikari Amoa-Gyarteng*
}

\begin{abstract}
This study aims to determine the importance of liquidity, profitability, asset productivity, activity, and solvency in cases of corporate financial distress. One hundred and five firms in the extractive industry in the United States were analyzed. Firms must be publicly traded and have filed form $10-\mathrm{K}$ reports with the securities and exchange commission of the United States to be considered for the study's population. The measure of corporate financial distress is the Altman Z-score. By using the Altman discriminant function, this study identifies the precipitants of corporate financial distress. This is especially important because widespread corporate financial distress could cause global financial system volatility. The indicators were measured in the last two years before the distressed firms declared bankruptcy. The results indicate that liquidity, profitability, asset productivity and solvency have an impact on the financial health of firms and therefore, on financial distress. The study further determines that activity ratio does not have a statistically significant relationship with financial distress.
\end{abstract}

Keywords: financial distress, profitability, liquidity, asset productivity, solvency, activity ratio.

\section{INTRODUCTION}

Global corporate bankruptcy cases have increased over the years. In the United States, for example, the number of businesses that filed for bankruptcy in the second quarter of 2016 increased by nine percent compared to the first quarter. The 2016 average number of bankruptcy filings per day in the same country was the highest in three years. Mining and oil and gas industries made up $40.79 \%$ of all public company bankruptcies in 2016. The three largest bankruptcies in the first half of 2016 in the United States were Sun Edison Inc., Peabody energy corporation and LINN energy, LLC (New Generation Report, 2016).

With the collapse of firms that had substantial asset value before their demise, the international financial system has become anxious for signs of financial distress and possible bankruptcy in firms (Outecheva, 2007). In this study, the precipitants of financial distress is identified using the Altman discriminant function. The Altman model is shown by many researchers such as Muller et al. (2009) to have the highest bankruptcy classification accuracy rate among all the bankruptcy predictor models. Consequently, the variables contained in the discriminant function are the most accurate to investigate financial distress.

In this study, financial distress is recognized as the state of falling into bankruptcy because of failure to take immediate remedial actions to exit the danger zone. A firm that is in financial distress may experience an unmanageable financial burden and declining operating performance which may lead to bankruptcy (Shiu \& Wang, 2014). Financial distress is a danger zone (Atkan, 2011), and firms must initiate

\footnotetext{
* Senior Lecturer. Dean-School of Graduate Studies, Ghana Baptist University College, PMB Amakom, Kumasi-Ghana. E-mail: k.amoagyarteng@gbuc.edu.gh.
} 
immediate actions to avert bankruptcy (Whitaker, 1999). The objective of this study is to assess the impact of profitability, liquidity, asset productivity, activity and solvency on financial distress.

\section{LITERATURE REVIEW}

Corporate bankruptcy prediction has gained interest because of the potential impact that the phenomenon has on shareholders, creditors, and the government $(\mathrm{Li}$, 2014). Corporate financial distress could even cause volatility in the entire global financial system (Li, 2014). Consequently, many studies, such as Altman (1968) have sought to predict financial distress. Altman (1968) used financial information as found on the financial statement of firms to assess the possibility of bankruptcy. The variables contained in the Altman function are profitability, liquidity, asset productivity, solvency, and activity.

Trivedi (2010) defined profitability as the ability of a firm to earn profits from its operations. Profit is what remains in the business after expenses have been deducted. Even though profits and profitability are sometimes used interchangeably, Trivedi (2010) posited that they are not the same as profitability is a relative term, and profit is an absolute concept.

Gopalan et al. (2012) noted that a liquid asset is one that can be turned into cash quickly and at a low cost. Firms that have relatively high liquidity can turn their assets into cash fast and can meet their short-term obligations. Liquidity assesses the ability of the firm to match cash outflows with adequate cash inflows and the capacity of the firm to withstand unanticipated events such as an upsurge of expenses or a decline in cash outflows (Doina \& Mircea 2008). In this study, the term liquidity refers to the firm's ability to convert assets to cash at a considerable rate to be able to meet demands from creditors.

Asset productivity measures the operating profits a firm generates from total assets. According to Altman (1968), asset productivity ratio is one of the most significant variables for studies on corporate distress. Ferrouhi (2014) noted that solvency is the capacity of an organization to fulfil obligations in the event of a liquidation. Firms can only have that capacity when assets exceed or meet total liabilities (Ferrouhi, 2014). If assets are lower than liabilities, then the firm faces insolvency risk. Activity ratios measure how efficiently the firm uses and controls its assets (ICAP, 2006).

\subsection{Bankruptcy}

Epstein et al. (2010) defined bankruptcy as a process which protects debtors from financial responsibilities that are impossible to meet. Financially distressed firms may file for bankruptcy protection. In distressed firms, liabilities exceed asset value (Altman, 2000). In this situation, the firm is not able to meet debtor demand and may declare bankruptcy. There are five basic bankruptcy types under the United States bankruptcy code (Mecham, 2004). They are chapter 7, chapter 9, chapter 11, chapter 12, and chapter 13. This study focused on chapter 7 and chapter 11 as they cover corporate bankruptcies. Under chapter 7 bankruptcy, the debtor is constrained to liquidation, and the debtor under chapter 11 is entitled to reorganize (Mecham, 2004).

There is a cost of financial distress which could either be direct or indirect. Direct cost includes legal and administrative expenses incurred in insolvency proceedings (Opler \& Titman, 1994). According to Rosslyn-Smith et al. (2019), indirect cost relates to loss of customer goodwill, loss of supplier goodwill, decreased employee morale and productivity, high employee turnover, inability to raise funding and 
inefficient asset sales. The indirect cost of financial distress is higher than the direct cost (Rosslyn-Smith et al., 2019). Indirect factors, as a result, can cause a financially distressed firm to deteriorate in terms of operating performance even more rapidly.

\subsection{Evolution of Bankruptcy Prediction Studies}

Corporate bankruptcy prediction was started in 1935 by Smith and Winakor in the era of the great depression (Altman, 1993). Merwin in 1942 was able to prove that distressed firms and non-distressed firms showed significantly different financial ratios (Sung et al., 1999). Three ratios that Merwin (1942) predicted to be important indicators of financial distress included net working capital to total assets, current ratio, and net worth to total debt.

Jackendoff (1962) analyzed the current ratio and working capital to total assets ratio and concluded that they are higher for profitable firms relative to distressed firms. Jackendoff (1962) further noted that worth to debt ratio in healthy firms is lower compared to financially distressed firms). Early studies between 1935 and 1966 formed the basis for the development of bankruptcy prediction models (Bellovary et al., 2007).

\subsection{Review of Literature on Determinant Frameworks of Financial Distress}

Financial distress may lead to bankruptcy, which, according to Kyung-Sung et al. (1999), brings economic losses to stakeholders including employees, customers, equity holders and managers. Accurate prediction of bankruptcy is, therefore, an important topic in corporate finance (Kyung-Sung et al., 1999). In most bankruptcy prediction studies; independent variables are empirically chosen from the financial statement and a functional form developed between the variables to give a predictive score that indicates whether or not a firm is in distress.

According to Latinen and Latinen (2000), the variables are chosen based on their importance in literature or their statistical univariate and multivariate significance. Most predictor models accurately predict bankruptcy. Dugan and Zavgren (1988) established that several models such as Beaver (1966), Altman (1968), Deakin (1972), Blum (1974), Diamond (1976) and Ohlson (1980) can predict bankruptcy with $85 \%$ to $95 \%$ accuracy.

Bankruptcy prediction studies regularly use multiple discriminant analysis (MDA), logit analysis or probit multivariate statistical tools (Dugan \& Zavgren, 1988). Multivariate approaches, unlike univariate techniques, use several financial ratios concurrently to determine the possibility of bankruptcy. Multiple discriminant analysis assigns coefficients to financial values which are then summed up to arrive at a score. The score is then used to classify the firm as bankrupt or healthy.

The Altman Z-score model has been shown by many studies to have a superior financial distress predictive ability compared to other models. For instance, in evaluating the predictive capacity of different bankruptcy models, Chung et al. (2008) observed that the Altman index surpassed other financial distress measures one year before bankruptcy. Machek (2014) estimated the percentage of situations where bankruptcy prediction models accurately predicted business failures. The study found that the Altman Z-score was more efficient in predicting financial distress than other models.

\subsection{Synthesis of the Research}

Recurring liquidation of firms has resulted in increased anxiety for signs of financial distress (Outecheva, 2007). Financial distress could result in bankruptcy (Steyn-Bruwer \& Hamman, 2006). There have been several studies that predict financial distress (Bellovary et al., 2007). Bellovary et al. (2007) noted that modern bankruptcy prediction started with the univariate studies of Beaver (1966). 
Following Beaver (1966), Altman (1968) developed an algorithmic model based on multivariate analysis. Altman's (1968) original model had five variables categorized into liquidity, profitability, asset productivity, solvency, and activity indices (Altman, 2000). The five variables have subsequently been confirmed by various studies to be good indicators of financial distress.

Brindescu-Olariu (2016) validated the utility of profitability in predicting bankruptcy. Khani and Guruli (2015) used liquidity ratios to predict bankruptcy. The liquidity ratios were cash flow to assets ratio, cash flow to debt ratio, cash flow to current liabilities and cash flow to sales ratio. According to Khani and Guruli (2015), liquidity ratios are capable of predicting bankruptcy up to two years before liquidation.

Rashid and Abbas (2011) studied the ratios that are most significant in bankruptcy prediction for non-finance firms in Pakistan. The study involved 24 variables that measured profitability, liquidity, leverage, and turnover. They developed a model that had 76.9\% bankruptcy prediction accuracy. Al-Kassar and Soileau (2014) examined models that used solvency to predict bankruptcy. The study involved data from six companies between 1998 and 2011. Al-Kassar and Soileau (2014) concluded that solvency models led to accurate prediction of bankruptcy.

According to Altman (2013), profitability, liquidity and solvency ratios were the most significant indicators of financial distress and possible bankruptcy. AmoaGyarteng (2019b) extended the extant literature by using a structure coefficient index to identify profitability as the most significant factor in situations of bankruptcy. By using 105 bankrupt firms in the extractive industry in the United States, this study will determine the impact that liquidity, profitability, asset productivity, asset productivity, solvency and activity ratios have on financial distress.

\subsection{Scope of the Study}

The scope of this study was limited to public mining and oil and gas firms in the United States that went bankrupt between 2006 and 2016. The Altman (1968) model has gone through several variations (Altman, 2000). The original model had an initial sample of manufacturing firms and predicted bankruptcy for public firms (Altman, 1968). This study used the original Altman (1968) model as its foundation and hence the ensuing scope of only public firms. Additionally, financial data for public firms are easy to access, as they are obligated to file their financial statements with the securities and exchange commission (SEC, 2009).

\subsection{Research Design}

Polit and Hungler (1999) described research design as the blueprint that will answer research questions to obtain accurate results. The research design for this study is quantitative correlational. The study seeks to understand the relationship between the variables in the Altman (1968) bankruptcy prediction model and financial distress. Previous studies such as Ohlson (1980), Zmijewski (1984) and Rose-Green and Lovata (2013) used quantitative design to understand the concept of financial distress and to formulate bankruptcy prediction models. The Altman Z-score and the individual variables in the Altman (1968) model will be statistically analyzed for the strength of association.

\subsection{Hypotheses Development}

The objective of this study is to assess the impact of the individual Altman indices on financial distress. The Altman Z-score is used in this study as a proxy for financial distress. The Z-score measures financial distress as posited by Altman (1968). The primary assumption in this study is that the Altman algorithm model accurately 
predicted bankruptcy in all the sampled firms and that the Z-score is an accurate measure of financial distress in the sampled mining and oil and gas firms.

As a result, the following hypotheses were tested:

$\mathbf{H}_{\mathbf{a}}$ : there is a statistically significant relationship between liquidity and the Altman Zscore of financially distressed firms in the last two years preceding bankruptcy.

$\mathbf{H}_{\mathrm{b}}$ : there is a statistically significant relationship between profitability and the Altman Z-score of financially distressed firms in the last two years preceding bankruptcy.

$\mathbf{H}_{\mathrm{c}}$ : there is a statistically significant relationship between asset productivity and the Altman Z-score of financially distressed firms in the last two years preceding bankruptcy.

$\mathbf{H}_{\mathrm{d}}$ : there is a statistically significant relationship between solvency and the Altman Zscore of financially distressed firms in the last two years preceding bankruptcy.

$\mathbf{H}_{\mathrm{e}}$ : there is a statistically significant relationship between activity ratio and the Altman Z-score of financially distressed firms of distressed firms in the last two years preceding bankruptcy.

\section{RESEARCH SAMPLE AND METHODOLOGY}

\subsection{Population and Sampling Strategy}

According to Polit and Hungler (1999), a population is a complete pool that is of interest to the researcher. LoBindo-Wood and Haber (1998) stated that a sample is the subset of the population from which generalizations could be made. The population of this study is all U.S. firms in the extractive industry that filed for chapter 11 or chapter 7 bankruptcy between 2006 and 2016.

The population selection is similar to Platt et al. (1994) who used logit analysis to develop a model to assess bankruptcy. El-Temtamy (1995) used a population of U.S oil and gas firms to develop a bankruptcy prediction model, which had $71.43 \%$ to $100 \%$ accuracy rate for bankrupt firms and $91.5 \%$ to $100 \%$ accuracy rate for non-bankrupt firms. Other studies that mirror the population selection of this study include Skogvisk (1990) and Yang et al. (1999) who developed a bankruptcy prediction model by using oil and gas companies.

Sampling should be done such that the sample is representative of the population (Bryman \& Bell, 2011). When a sample is representative of the population, the findings can be generalized as attested to by Bryman and Bell (2011). In this study, a random sampling technique is used. As stated by Triola (2009), a minimum sample size of 30 in a quantitative study guarantees a normal distribution for parametric regression analysis. This study consists of 105 financially firms drawn over ten years.

\subsection{Research Instrument}

The research instrument is the device used to collect data (Biddix, 2009). Data for this study is secondary and is found in the audited financial statements of the sampled firms. Meigs and Meigs (2003) defined the financial statement as a structured representation of the financial situation of the firm. The financial statement is, therefore, a datasheet that collects financial information on firms. In this study, financial statement data that were utilized by Altman (1968) were used. The data are as follows:

1) Current assets.

2) Current liabilities.

3) Total assets.

4) Retained earnings. 
5) Earnings before interest and taxes.

6) Market value of equity.

7) Book value of debt.

8) Sales.

The above financial statement data were used to derive the five variables in the Altman (1968) algorithm function and the overall Z-score as follows:

$$
Z=0.012 X_{1}+0.014 X_{2}+0.033 X_{3}+0.006 X_{4}+0.999 X_{5}
$$

Where:

$\mathrm{Z}=$ Altman's overall index,

Liquidity $\left(\mathrm{X}_{1}\right)=$ working capital/total assets,

Profitability $\left(\mathrm{X}_{2}\right)=$ retained earnings/total assets,

Asset productivity $\left(\mathrm{X}_{3}\right)=$ earnings before interest and taxes/ total assets,

Solvency $\left(\mathrm{X}_{4}\right)=$ market value of equity/book value of total liabilities, and

Activity $\left(\mathrm{X}_{5}\right)=$ sales $/$ total assets.

\subsection{Instrument Validation}

Validity is the degree of accuracy of the research instrument in measuring what it is designed to measure (Giddaiah, 2016). Three forms of validity include content validity, predictive validity and construct validity (Creswell, 2009). With secondary data, the major concern is content validity and whether proxies correspond to the domain of the construct (Rindfleish \& Heide, 1997). In the original Altman (1968) model, the bankruptcy prediction accuracy was $95 \%$ indicating that the concern of content validity as enumerated by Rindfleish and Heide (1997) was not a factor. This study is using the same financial statement information as Altman (1968); therefore, content validity is established.

The data for this study is recorded on financial statements representing "real" decisions that have been made by "real" industry players in "real" environments (Winer, 1999). Financial data, such as those used in this study, are based on the guidelines of the securities and exchange commission (Winer, 1999). A reasonably prepared financial statement is factual, free from bias, and presents an accurate representation of the economic situation of a firm (Szivos, 2014).

As a result of audits and stringent applicable financial reporting mechanisms, financial statements are standardized and reliable (Szivos, 2014). The source of financial data in large firms such as those analyzed in this study is handled by enterprise resource planning systems (ERP) and other software making the reliability of financial statements assured. In the opinion of Szivos (2014), control procedures are enforced, and therefore, the data contained in the financial statement are valid and an accurate representation of the state of the organization.

\subsection{Data Collection Procedures}

In this study, mining and oil and gas firms that declared bankruptcy between 2006 and 2016 in the United States were investigated. Financial distress in this study, as in Ohlson (1980) is described as firms that have filed for bankruptcy. Corporate bankruptcy may be either chapter 7 or chapter 11 bankruptcy. Under this description, 144 listed firms went bankrupt. For this study, only publicly listed firms were considered. Private firms were not part of the population of this study because of difficulty in assessing data as attested to by several researchers such as Altman (1968) and Sung et al. (1999).

Only two industries that are closely aligned were involved in this study. This is to avoid the industry effect, which Altman (1984) explained is the result of dissimilarities among industries. The collection of data from only mining and oil and gas firms is 
because they made up approximately half of all public firms that declared bankruptcy between 2015 and 2016 in the United States (New Generation Report, 2016).

Size of assets, size of liabilities, and the number of employees were not part of the data selection criteria. List of bankrupt firms was gathered from the Bankruptcy Yearbook and Almanac, which publishes the new generation report, a compilation of U.S. Bankruptcy data. Financial statement data were then retrieved from the $10 \mathrm{~K}$ reports filed with the United States securities and exchange commission.

\subsection{Analysis}

Correlation analysis was used to test for statistically significant relationships between the variables. Correlation determines the strength and direction of a linear relationship between continuous variables (Laerd, 2015). According to Cohen (1988), a correlation coefficient of 0.1 to 0.3 is classified as small, a correlation coefficient of 0.3 to 0.49 is classified as moderate, and a correlation coefficient of more than 0.49 is classified as strong.

This study assesses the relationship between financial distress and all the independent variables in the Altman (1968) discriminant function. To accept or reject the various hypotheses, Pearson's product-moment correlation is used. The correlation coefficient is determined to be statistically significant if the level of significance is less than 5 percent. Guidelines for determining the strength of association between variables were provided by Cohen (1988) as follows:

\begin{tabular}{cc}
\hline Coefficient Value & Strength of Association \\
\hline $0.1<|\mathrm{r}|<0.3$ & Weak Correlation \\
$0.3<|\mathrm{r}|<0.5$ & Moderate Correlation \\
$|\mathrm{r}|>0.5$ & Strong Correlation \\
\hline
\end{tabular}

\section{EMPIRICAL RESULTS}

Table 1 illustrates the correlation between liquidity and the Altman Z-score one year $(\mathrm{t}-1)$ and two years $(\mathrm{t}-2)$ preceding bankruptcy.

Table 1

Pearson Correlation between Liquidity and Altman Z-score

One Year (t-1) and Two Years ( $t-2)$ before Bankruptcy

\begin{tabular}{lcc}
\hline & Altman Z-score & P-value \\
\hline Liquidity (t-1) & 0.192 & 0.025 \\
Liquidity (t-2) & 0.816 & 0.000 \\
\hline
\end{tabular}

There is a statistically significant relationship, and a weak positive correlation between liquidity and the Altman Z-score one year before bankruptcy, $r(103)=0.192$, $\mathrm{p}<0.05$. There is also a statistically significant relationship, and a strong positive correlation between liquidity and the Altman Z-score two years before bankruptcy, $\mathrm{r}(103)=0.816, \mathrm{p}<0.05$. The hypothesis $\left(\mathrm{H}_{\mathrm{a}}\right)$ is, therefore accepted.

Table 2 illustrates the correlation between profitability and the Altman Z-score one year $(\mathrm{t}-1)$ and two years $(\mathrm{t}-2)$ preceding bankruptcy.

Table 2

Pearson Correlation between Profitability and Altman Z-score

One Year (t-1) and Two Years (t-2) before Bankruptcy

\begin{tabular}{lcc}
\hline & Altman Z-score & P-value \\
\hline Profitability (t-1) & 0.962 & 0.000 \\
Profitability (t-2) & 0.911 & 0.000 \\
\hline
\end{tabular}


Profitability and the Altman Z-score one year before bankruptcy have a statistically significant relationship and a strong positive correlation, $r(103)=0.962$, $\mathrm{p}<0.05$. There is also a statistically significant and strong positive correlation between profitability and the Altman Z-score two years prior to bankruptcy, $r(103)=0.911$, $\mathrm{p}<0.05$. As a result, the hypothesis $\left(\mathrm{H}_{\mathrm{b}}\right)$ is accepted.

Table 3 illustrates the correlation between asset productivity and the Altman Zscore one year ( $\mathrm{t}-1)$ and two years $(\mathrm{t}-2)$ preceding bankruptcy.

Tables 3

Pearson Correlation between Asset Productivity and Altman Z-score

One Year (t-1) and Two Years ( $t-2)$ before Bankruptcy

\begin{tabular}{lcc}
\hline & Altman Z-score & P-value \\
\hline Asset productivity (t-1) & 0.844 & 0.000 \\
Asset productivity (t-2) & 0.274 & 0.002 \\
\hline
\end{tabular}

There is a statistically significant relationship and strong positive correlation between asset productivity and the Altman Z-score one year before bankruptcy, $\mathrm{r}(103)=0.844, \mathrm{p}<0.05$. There is also a statistically significant relationship, and a weak positive correlation between asset productivity and the Altman $\mathrm{Z}$-score two years preceeding bankruptcy, $\mathrm{r}(103)=0.274, \mathrm{p}<0.05$. The hypothesis $\left(\mathrm{H}_{\mathrm{c}}\right)$ is accepted.

Table 4 illustrates the correlation between solvency and the Altman Z-score one year $(\mathrm{t}-1)$ and two years $(\mathrm{t}-2)$ preceding bankruptcy.

Table 4

Pearson Correlation between Solvency and Altman Z-score

One Year (t-1) and Two Years ( $\mathrm{t}-2)$ before Bankruptcy

\begin{tabular}{lcc}
\hline & Altman Z-score & P-value \\
\hline Solvency (t-1) & -0.287 & 0.001 \\
Solvency (t-2) & 0.182 & 0.031 \\
\hline
\end{tabular}

Solvency has a statistically significant relationship and a weak negative association with the Altman Z-score one year before bankruptcy, $r(103)=-0.287$, $\mathrm{p}<0.05$. Solvency has a statistically significant relationship, and a weak positive association with the Altman Z-score two years prior to bankruptcy, $r(103)=0.182$, $\mathrm{p}<0.05$. The hypothesis $\left(\mathrm{H}_{\mathrm{d}}\right)$ is accepted.

Table 5 illustrates the correlation between solvency and the Altman Z-score one year ( $\mathrm{t}-1)$ and two years ( $\mathrm{t}-2)$ preceding bankruptcy.

Table 5

Pearson Correlation between Activity and Altman Z-score

One Year (t-1) and Two Years (t-2) before Bankruptcy

\begin{tabular}{lcc}
\hline & Altman Z-score & P-value \\
\hline Activity (t-1) & -0.344 & 0.364 \\
Activity(t-2) & 0.016 & 0.437 \\
\hline
\end{tabular}

There is no statistically significant relationship between activity and Altman Z-score one year before bankruptcy, $\mathrm{r}(103)=-0.340, \mathrm{p}>0.05$. Furthermore, there is no statistically significant relationship between activity ratio and Altman Z-score two years before bankruptcy, $r(103)=-0.016, p>0.05$. The result fails to accept the hypothesis $\left(\mathrm{H}_{\mathrm{e}}\right)$. The lack of statistical significance is because the correlation between activity ratio and the Altman Z-score could occur by chance more than five times in a trial of 100 (0.05) which is the set alpha level. There is, therefore, no evidence that the hypothesis is true. 


\section{CONCLUSION}

\subsection{Conclusions and Implications}

This study examined the importance of liquidity, profitability, asset productivity, activity and solvency as firms approached bankruptcy. The empirical results reveal that liquidity has a significant and positive relationship with financial distress, one year and two years before bankruptcy. In this study, liquidity was measured as working capital relative to total assets. For firms to be financially healthy and prevent financial distress, they have to optimize working capital by increasing current assets.

Profitability was revealed in this study to have a strong positive relationship with financial distress in the last two years before bankruptcy. This is in line with AmoaGyarteng (2019b) who identified profitability as the most significant variable in the financial distress equation. This study quantified profitability as retained earnings in proportion to total assets. Ploughing back profits push firms to use funds judiciously. Profits, therefore, may end up getting compounded. To avoid financial distress, companies must make effective use of profits.

The strength of association between asset productivity and financial distress increase as the financial health of firms deteriorates. In this study, asset productivity was computed as earnings before interest and tax proportionate to total assets. This is an efficiency measure which indicates that firm managers should be efficient such that relatively small total assets are used to generate high earnings. It is a precursor to good firm financial health.

The relationship between solvency and financial distress was found to be a weak one, even as it is statistically significant. The results indicate a weak negative impact on financial distress as firms got closer to bankruptcy. Activity ratio was found not to have any effect on the financial distress of firms. The results of this study have shown that firms should increase current assets and not engage in over-investment in property, plant, and equipment. In addition, companies need to retain earnings and maximize efficiency.

\section{REFERENCES}

Al-Kassar, T. A., \& Soileau, J. S. (2014, October). Financial performance evaluation and bankruptcy prediction (failure). Arab Economic \& Business Journal, 9(2), 147-155.

Altman, E. (1968). Financial ratios, discriminant analysis and the prediction of corporate bankruptcy. The Journal of Finance, 23(4), 589-609.

Altman, E. I. (1984). The success of business failure prediction models: An international survey. Journal of Banking \& Finance, 8(2), 171-198.

Altman, E. (1993). Corporate Financial distress and bankruptcy (3 ${ }^{\text {rd }}$ ed.). New York, USA: John Wiley \& Sons, Inc.

Altman, E. I. (2013). Predicting financial distress of companies: revisiting the Z-score and ZETA® models. In Adrian R. Bell \& Marcel Prokopczuk (Eds.), Handbook of research methods and applications in empirical finance (chapter 17, pp. 428-456). Camberley Surrey, UK: Edward Elgar Publishing.

Amoa-Gyarteng, K. (2019a, January). Explanatory and predictive values of the drivers of corporate bankruptcy. Journal of Finance \& Marketing, 3(2), 1-8.

Amoa-Gyarteng, K. (2019b, April). Financial characteristics of distressed firms: An application of the Altman algorithm model. Journal of Corporate Accounting \& Finance, 30(1), 63-76. 
Atkan, S. (2011). Early warning system for bankruptcy prediction. Unpublished Doctoral Dissertation, Economics and Management Department, Karlsruhe Institute of Technology, Germany.

Beaver, W. H. (1966). Financial ratios as predictors of failure. Journal Accounting Research, $4,71-111$.

Bellovary, J. L., Giacomino, D. E., \& Akers, M. D. (2007). A review of bankruptcy prediction studies: 1930 to present. Journal of Financial Education, 33, 1-42.

Biddix, P. J. (2009). Research rundowns: Uncomplicated reviews of educational research methods. Quantitative research (QUANT)-descriptive and inferential statistics. Retrieved August 21, 2017, from https://researchrundowns.com/quantitative-methods/ instrument-validity-reliability/.

Brindescu-Olariu, D. (2016). Profitability ratio as a tool for bankruptcy prediction. SEA-Practical Application of Science, 4(11), 369-372.

Bryman, A. \& Bell, E. (2011). Business research methods (3 ${ }^{\text {rd }}$ ed.). New York, USA: Oxford University Press Inc.

Chung, K.-C., Tan, S. S., \& Holdsworth, D. K. (2008, January). Insolvency prediction model using multivariate discriminant analysis and artificial neural network for the finance industry in New Zealand. International Journal of Business \& Management, 3(1), 19-29.

Cohen, J. (1988). Statistical power analysis for the behavioral sciences (2nd ed.). Hillsdale, NJ: Lawrence Earlbaum Associates.

Creswell, J. W. (2009). Research design: Qualitative, quantitative, and mixed methods approaches ( $3^{\text {rd }}$ ed.). Thousand Oaks, CA: Sage Publications.

Doina, P., \& Mircea, M. (2008). Analysis of a company's liquidity based on its financial statements. Anuals of the University of Oradea, Economic Science Series, 17(3), 13661371.

Dugan, M. T., \& Zavgren, C. V. (1988). Bankruptcy prediction research: A valuable instructional tool. Issues in Accounting Education, 3(1), 48-64.

El-Temtamy, O. S. (1995). Bankruptcy prediction: A comparative study of logit and neural networks. Unpublished Doctoral Dissertation, Economics and Finance Department, Middle Tennessee State University, Murfreesboro, USA.

Epstein, D. G., Markell, B. A., Nickles, S. H., \& Perris, E. L. (2010, June). Bankruptcy: Materials and cases ( $3^{\text {rd }}$ ed.). M.N., USA: West Academic Publishing.

Ferrouhi, E. M. (2014). Bank liquidity and financial performance: Evidence from Moroccan banking industry. Verslas: Teorija ir praktika, 15(4), 351-361.

Giddaiah, D. (2016). Types of data collection tools. Retrieved July 15, 2017, from http://www.uni-mysore.ac.in/courseworklisc/ppt/pptsem_Giddaiich.pptx.

Gopalan, R., Kadan, O., \& Pevzner, M. (2012, April). Asset liquidity and stock liquidity. The Journal of Financial \& Quantitative Analysis, 47(2), 333-364.

ICAP. (2006). Financial ratios explanation. ICAP Group South Africa. Retrieved August 27, 2016, from https://www.icapb2b.gr/b2b_web/CMSContent/FINANCIAL _RATIOS.pdf.

Jackendoff, N. (1962). A study of published industry financial and operating ratios (vol. 52). Bureau of Economic and Business Research. Philadelphia: Temple University.

Khani, A. H., \& Guruli, M. R. (2015). Predicting bankruptcy by liquidity ratios analysis. Journal UMP Social Sciences \& Technology Management, 3(2), 372-380.

Kyung-Sung, T., Chong, N., \& Gunhee, L.C. (1999). Dynamics of modeling in data mining: Interpretive approach to bankruptcy prediction. Journal of Management Information Systems, 10(1), 63-85. 
LaBiondo-Wood, G., \& Haber, J. (1998). Nursing research: Methods, critical appraisal, and utilization (6 $6^{\text {th }}$ ed.). St. Louis, MO: Mosby.

Laerd Statistics (2015). How to perform a multiple regression analysis in SPSS statistics. Retrieved January 9, 2017 from http://www.statistics.laerd.com.

Latinen, E. K., \& Latinen, T. (2000, December). Bankruptcy prediction: Application of the Taylors expansion in logistic regression. International Review of Financial Analysis, 9(4), 327-349.

Li, W. G. (2014). Corporate financial distress and bankruptcy prediction in the North American construction industry (pp. 1-43). Duke University, Durham, North Carolina.

Mecham, L. R. (2004, April). Bankruptcy basics: Applicable to cases filed before October 17, 2005 (revised 2nd ed.). The Bankruptcy Judges Division, Administrative Office of the United States Court, Washington, D.C.

Meigs, W. B., \& Meigs, R. F. (2003). Financial accounting (13 ${ }^{\text {rd }}$ ed.). New York, USA: McGraw-Hill, Inc.

Merwin, C. L. (1942). Financing small corporations in five manufacturing industries. New York: National Bureau of Economic Research.

Muller, G. H., Steyn-Bruwer, B. W., \& Hamman, W. D. (2009, March). Predicting financial distress of companies listed on the JSE-A comparison of techniques. South African Journal of Business Management, 40(1), 21-32.

New Generation Report. (2016). Corporate bankruptcy recap: Bankruptcies up 41\% of filings from oil \& gas/energy. Retrieved January 9, 2017, from http://www.bankruptcydata.com.

Ohlson, J. A. (1980). Financial ratios and the probabilistic prediction of bankruptcy. Journal of Accounting Research, 18(1), 109-131.

Opler, T. C., \& Titman, S. D. (1994, February). Financial distress and corporate performance. The Journal of Finance, 49(3), 1015-1040.

Outecheva, N. (2007). Corporate financial distress: An empirical analysis of distress risk. Unpublished Doctoral Dissertation. Graduate School of Business Administration, University of St. Gallen, Switzerland.

Polit, D. F., \& Hungler, B. P. (1999). Nursing research: Principles and methods (6 $6^{\text {th }}$ ed.). Philadelphia: Lippincott.

Platt, H. D., Platt, M. B., \& Pedersen, J. G. (1994, June). Bankruptcy discrimination with real variables. Journal of Business Finance \& Accounting, 21(4), 491-509.

Rashid, A., \& Abbas, Q. (2011). Predicting bankruptcy in Pakistan. Theoretical \& Applied Economics, 18(9), 103-128.

Rindfleish, A., \& Heide, J. B. (1997, October). Transaction cost analysis: Past, present and future applications. Journal of Marketing, 61(4), 30-54.

Rose-Green, E., \& Lovata, L. (2013). The relationship between firms' characteristics in the periods prior to bankruptcy filing and bankruptcy outcome. Accounting \& Finance Research, 2(1), 97-109.

Rosslyn-Smith, W., De Abreu, N. V. A., \& Pretorius, M. (2019). Exploring the indirect costs of a firm in business rescue. South African Journal of Accounting Research, 34(1), 24-44.

Securities and Exchange Commission (SEC) (2009). Interactive data for financial reporting. Retrieved February 20, 2016, from http://www.sec.gov/info/smallbus/ secg/interactivedata-secg.html.

Shiu, H.-R., \& Wang, M.-J. (2014, January). Research on the common characteristics of firms in financial distress into bankruptcy or recovery. Investment Management \& Financial Innovations, 2(4), 233-243. 
Skogvik, K. (1990). Current cost accounting ratios as predictors of business failure: The Swedish case. Journal of Business Finance \& Accounting, 17(1), 137-160.

Steyn-Bruwer, B. W., \& Hamman, W. D. (2006). Company failure in South Africa: Classification and prediction by means of recursive partitioning. South African Journal of Business Management, 34(4), 1-12.

Sung, T. K., Chang, N., \& Lee, G. (1999). Dynamics of modeling in data mining: Interpretive approach to bankruptcy prediction. Journal of Management Information Systems, 16(1), 63-85.

Szívós, L., \& Orosz, I. (2014). The role of data authentication and security in the audit of financial statements. Acta Polytechnica Hungarica, 11(8), 161-176.

Triola, M. F. (2009). Elementary statistics (11 th ed.). New York, USA: Addison Wesley.

Trivedi, S. M. (2010, March). An analysis of financial performance of state road transport corporation in Gujarat. Unpublished Doctoral Dissertation, Department of Business Management, Saurashtra University, Gujarat, India.

Whitaker, R. (1999). The early stages of financial distress. Joumal of Economics \& Finance, 23(2), 123-132.

Winer, R. S. (1999, July). Experimentation in the $21^{\text {st }}$ century: The importance of external validity. Journal of the Academy of Marketing Science, 27(3), 349-358.

Yang, Z. R., Platt, M. B., \& Platt, H. D. (1999, February). Probabilistic neural networks in bankruptcy prediction. Journal of Business Research, 44(2), 67-74.

Zmijewski, M. E. (1984). Methodological issues related to the estimation of financial distress prediction models. Journal of Accounting Research, 22, 59-82. 